\title{
Subnational institutions and open innovation: Evidence from China
}

\begin{abstract}
Under what subnational institutional conditions does open innovation strategy enhance the innovativeness of emerging market enterprises (EMEs)? Using a novel dataset of Chinese high-tech manufacturing firms over the period of 2008 and 2011, we show that although on average openness to external actors improves innovation performance this effect is pronounced for EMEs that operate in subnational regions with a higher level of intellectual property rights (IPR) enforcement and of factor market development. Our findings point to the context-dependent nature of open innovation strategy and the complementary effect of institutional parameters in emerging markets and help to reconcile the contrasting findings regarding the effect of open innovation in the prior literature.
\end{abstract}

Key words: Open innovation, institutions, subnational regions, performance, Chinese firms

\section{Introduction}

Open innovation (OI) strategy emphasizes the importance of openness to external knowledge sources such as suppliers, customers, and competitors, as opposed to the traditional 'closed innovation' model in which firms innovate solely on the basis of their in-house capabilities (Chesbrough, 2003; Lauren and Salter, 2006; 2014). Prior studies have provided valuable insights indicating that the OI strategy overcomes the liability of un-connectedness (Chesbrough, 2003) and improves a firm's patenting success and development of new products (Laursen and Salter, 2014; Noh, 2015; Zhang et al., 2017). Openness in innovation process may be particularly important for latecomer emerging market enterprises (EMEs) to catch up in the global battle for technology leadership because these firms need to draw in knowledge from external sources to compensate for their lack of internal capabilities (Hong et al., 2015; Kafouros et al., 2015) and develop innovation. 
Prior studies, drawing upon institutional theory (North, 1990), acknowledge that well-developed institutions support innovative activities by providing innovation infrastructure, factor markets and protection of intellectual property rights (IPR) that reduces uncertainty and transaction costs and facilitates market-based exchanges (Khanna and Yafeh, 2007; Zhang and Zheng, 2017). However, these studies often assume that the institutional context remains the same across different subnational regions within a given country and, as a result, the role of subnational institutions in shaping the performance outcomes of $\mathrm{OI}$ is under-theorized. This neglect is surprising because institutions are heterogeneous across subnational regions within a country (North, 1990; Wang et al., 2015) that may account for variations in the performance outcomes of the OI strategy between firms. Furthermore, prior assumptions and findings that have informed the OI theory and managers are largely based on studies of developed countries where firms have strong internal capabilities and operate in institutional environments that encourage innovative activities. The significant ways in which EMEs differ from their counterparts in developed economies in terms of internal capabilities and institutional context limit scholarly understanding of what shapes the performance outcomes of EMEs' open innovation.

This study aims to address these research gaps by developing and testing a context-dependent perspective of OI using a sample of high-tech Chinese manufacturing firms. Building on previous advances (e.g., Hong et al., 2015; Wang et al., 2015), we join the literatures on OI and institution-based view in trying to consider the participatory and endogenous role of subnational institutions in shaping the outcomes of OI. We posit that there are significant variations in institutions across subnational regions within a given emerging country such as China that create both opportunities and challenges for EMEs' innovative activities which in turn depict the boundary conditions with respect to when OI strategy enhances innovation performance. Specifically, we consider three region-specific institutions, namely the levels of IPR enforcement, factor market development and intermediation market development, and propose that other things being equal, these cross-regional differences in institutions can explain variations in the effect of OI strategy on innovation performance. The analysis of subnational institutions is important because it extends prior theoretical predictions by explaining why firms with similar 
characteristics can yield different returns from OI and why this innovation model is likely to be more beneficial in some regions than in others. By demonstrating how location-specific institutional idiosyncrasies influence the effectiveness of the OI model, our study advances understanding of how and which institutions influence the performance outcomes of OI and also provides guidelines for how managers should formulate strategies of openness and maximize the benefits from OI.

Because China has a large number of sub-national regions that demonstrate a significant heterogeneity in institutional landscape (Hong et al., 2015; Wang et al., 2015), it offers a promising context in which to explore the relationship between OI, region-specific institutions and innovation performance. We examine these relationships using a longitudinal dataset of 438 Chinese high-tech manufacturing firms during 2008-2011. Our findings indicate that the effect of OI on performance is stronger for Chinese firms in regions with stronger IPR enforcement and with a higher level of factor market development. Although our analysis focuses mainly on China, a number of the predictions of our framework could be adapted to other emerging economies.

\section{Theoretical framework}

\subsection{Benefits and costs of open innovation model}

The OI model emphasizes the importance of opening up of innovation process to external players for developing innovation (Chesbrough, 2003; Lauren and Salter, 2006; 2014). It suggests that the advantages of merely focusing on the development of internal capabilities have declined and, as a result, the importance of openness to and interaction with external partners has increased (Chesbrough, 2003). OI differs from academic collaborations defined as a firm's involvement with universities and research institutes (URIs) or other academic institutions in its process of developing innovations (Kafouros et al., 2015). It is wider than academic collaborations in terms of the scope of external engagement and involves not only academic institutions but also all other types of external players such as suppliers, customers, and competitors. Academic collaborations can be a key part of a firm openness depending on the extent to 
which a firm relies on academic institutions vs other external players in its external engagement of technological collaborations.

The OI model offers a number of advantages over the 'closed' innovation model where a firm develops and commercializes innovations largely within its own boundary (Chesbrough, 2003). First, the OP model enhances firms' ability to create innovation. The opening up of innovation process by integrating external actors helps firms find sources of variety in resources and knowledge, enabling them to replace one set of knowledge-intensive factors with an alternative one (Jacobides et al., 2006). Openness to competitors, for example, allows firms to gain access to complementary knowledge and skills and track and monitor these competitors' activities which can guide and shape their own innovative efforts (Laursen and Salter, 2014). Similarly, collaboration with URIs enables firms to acquire new scientific knowledge, experiment with alternative designs, and explore new technological paths (Kafouros et al., 2015).

Second, openness to external knowledge sources enables firms to better appropriate returns from innovations (Memili et al., 2015). Integrating customers into the innovation process, for example, helps the firm respond more deftly to changes in consumer preferences, refine technology directions, and increase the likelihood of market acceptance of new products (Wu and Olk, 2014). Furthermore, because protection from imitation in emerging economies such as China depends not only on the law but also on the discretion of government agencies (LaPorta et al., 1997), collaborating with government agencies helps EMEs protect proprietary technology and therefore increase value capture from innovation.

However, OI may also have a negative effect on innovation performance. Opening of innovation processes incurs costs associated with searching for and coordinating an increasing number of new collaborations (Berchicci, 2013). Over-reliance on external collaborations can hinder development of internal R\&D processes which may ultimately hamper the firm's ability to capture and assimilate external knowledge (Berchicci, 2013). Technological collaborations with partners with different routines and mechanisms can create significant 'switching' costs because of the context-specific nature of these routines and mechanisms (Lhuillery and Pfister 2009). Furthermore, opening up of innovation process can 
lead to loss of knowledge and innovation skills (Laursen and Salter, 2014). Empirical evidence is in line with these arguments, showing that excessive reliance on external collaborations reduces a firm's innovative performance (Caputo et al., 2016; Laursen and Salter, 2006).

\subsection{The role of institutions in open innovation}

Institutions set the rules that form a country's legal infrastructure and incentive structures that govern economic transactions (North, 1990; Scott, 1995). As firms are an integral part of the national or regional institutional environment (Hong et al., 2015; North, 1990), their innovation decisions, strategy and performance are influenced by a multitude of institutional forces which either promote or hinder the upgrading of existing capabilities. An institutional approach is central to understanding the forces that shape EMEs' innovation outcomes because it helps us explain differences in innovation performance that do not result from variations in organizational factors.

Institutions influence OI and its outcomes in three ways. First, institutions influence the willingness of EMEs to engage in the opening up of innovation process. The regulatory forces, for example, can exert pressures through laws, regulations and policies that influence the inclination of EMEs' managers to engage in external technological partnerships. Similarly, normative expectations influence the willingness of EME managers to open up innovation process. These managers are more likely to adopt an OI strategy when they believe that openness to external knowledge sources will increase sales and ultimately boost their career prospects.

Second, institutions influence the ability of EMEs to utilize the OI model effectively. Welldeveloped capital markets, intermediaries and contract enforcement laws facilitate R\&D collaborations. Innovation intermediaries such as universities, regional trade associations, and technical assistance centers, for example, play the role of boundary spanners that help to overcome information asymmetry and bridge suppliers and customers (McEvily and Zaheer, 1999). Institutions also influence the effectiveness of OI strategy by affecting how firms have differential access to critical external resources, such as labour, capital and knowledge (Wang et al., 2015). Third, IPR regime affects not only firms' 
incentives to engage in OI but also the extent to which firms can appropriate value from innovations resulting from external collaborations.

Because differences in innovation-supporting institutions exist not only between but also within countries (Nelson, 1988), innovation is strongly influenced by subnational level institutions of a given country. Although this study focuses on China which is a large economy and features the growing importance of subnational regions due to recent administrative decentralization (Kafouros et al., 2015), we should note that many other emerging countries such as Israel, Malaysia, Uruguay and Kenya are also characterized by polycentric institutions like China (Choi et al., 2015). Hence, although the importance of subnational regions may vary across countries, accounting for the role of institutions at this level is important for understanding of what account for the effectiveness of OI.

\section{Hypotheses}

Although many emerging countries have IPR laws on paper, their enforcement provides innovators with little protection from imitators (Keupp et al., 2012). Strong IPP enforcement induces innovation by discouraging opportunistic behavior and reducing the risks of expropriation by collaborators (Ang et al., 2014). However, although the applicable IPRs laws and international treaties are the same within China, there exist significant differences in the enforcement of the IPP laws across regions (Kafouros et al., 2015) because of the uneven social and economic development across these regions (Fan et al., 2011).

We should recognize that though IPR is important for firms to appropriate value from innovations, the OI strategy and IPR protection and enforcement may be incompatible. OI involves disclosure of some of the firm's knowledge to external partners, but this may be conflicting with the needs of the protection of that knowledge from unwanted leakage, creating what Laursen and Salter (2014) call a 'paradox of openness'. Despite these arguments, however, we contend that the performance-enhancing effect of OI is higher in regions with stronger IPR enforcement than in regions with weaker IPR enforcement.

Strong IPR enforcement raises the costs of imitation and infringements, enabling firms to exploit ideas and IP generated from collaborative OI projects. EMEs in regions with stronger IPR enforcement 
receive greater protection from patent infringements and thus have more confidence in disclosing confidential information to external collaborators (Ang et al., 2014). As a result, they would be more willing to share resources, devote more efforts to technological collaborations and transfer technology and skills to their partners without destroying any competitive advantages they might have (Li, 2012). This in turn helps EMEs enhance the efficiency of OI and increase output in patents and sales from new products.

By contrast, in regions with weaker IPR enforcement, under-developed institutions spark fears of expropriation of proprietary technology. EMEs will find it difficult to gain protection against behaviors such as counterfeiting in $R \& D$ collaborations and to follow normal legal processes to mitigate the risk of appropriation by partners (Ang et al., 2014). In such cases, EMEs are reluctant to engage in OI, fearing that the opportunistic behavior of their partners will increase transaction costs and lower economic payoffs from innovation (Kafouros et al., 2015). Therefore, although openness may on average enhance innovation performance, we expect this effect to vary across subnational regions depending on the strength of IPR enforcement. Hence:

H1. The positive effects of open innovation on innovation performance will be higher for EMEs in regions with a higher-level IPR enforcement than for EMEs in regions with a lower level of IPR enforcement.

The development of factor markets refers to the extent to which the factors of production or innovation, such as labor, capital, and natural resources, are determined by the interplay of demand and supply forces rather than non-market forces (Hong et al., 2015). Although China has made great progress in transition to a market-based system since 1978, the Chinese government initially prioritized the development of China's eastern coastal regions only, e.g., by encouraging trade and FDI. As a result, the development of factor markets is heterogeneous across subnational regions within the country (Fan et al., 2007; 2011). Such cross-regional variations in factor market development influence the ability of EMEs to take advantage of OI and enhance innovation performance. 
In regions characterized by relatively well-developed factor markets, market-based mechanisms of economic exchanges reduce information asymmetry and uncertainty and lower transaction and search costs (North, 1990). In such regions, EMEs can take advantage of well-developed external factor markets to coordinate the operations of their innovation value chains. They will have more opportunities to broaden their innovation networks, gain access to advanced factors, and benefit from exchanges of factors. This in turn reduces transaction costs and business uncertainty about the legitimate ways of creating innovation from collaborations with external actors. For example, well-developed public equity markets can facilitate OI by serving to allocate capital, ameliorate problems associated with information and transaction costs involved (Levine, 1997), and make financing easily available for firms. Because information is less asymmetric in such regions, EMEs can relatively easily search for appropriate partners with lower cost.

By contrast, in regions with a lower level of factor market development, the markets for factors are dysfunctional (Fan and Wang, 2007) or are characterized by non-market forces such as relationship-based exchanges (Peng, 2003), burdensome regulatory restrictions (Hong et al., 2015), and political favoritism (Hong et al., 2015). In such cases, EMEs are likely to engage in costly market transactions, which makes searching for factors costly and hampers the firm's ability to capitalize on OI (Makino et al., 2002). EMEs are likely reluctant to open their innovation process because it is difficult to evaluate market information and curb opportunistic behavior (Lin et al., 2009). As a result, they have to rely on relational exchanges (Peng, 2003) which increase transaction costs and impede firms' ability to create innovation through external collaborations. Hence:

H2. The positive effects of open innovation on innovation performance will be higher for EMEs in regions with a higher level of factor market development than in regions with a lower level of factor market development. 
Market intermediaries can be defined as "economic agents who coordinate and arbitrate transactions between a group of suppliers and customers." (Wu, 2004: 67) and they include various types of intermediaries such as trade agents, financial intermediaries and innovation intermediaries. The development of intermediation markets in this study refers to the extent to which organizations use market intermediaries rather than their own means to coordinate economic exchanges. In the pre-reform era of China, intermediation markets were almost non-existent because government acted as intermediaries for overcoming market failure and for achieving equality of distribution. Although intermediaries have emerged following the economic reform programme implemented since 1978, the development of intermediation markets is highly skewed in terms of spatial distribution within the country (Fan et al., 2011). We argue that these variations in intermediation market development influence the effectiveness of OI for EMEs in different subnational regions.

In regions with more developed intermediation markets, intermediaries are more effective, provide reliable market information and formal infrastructures and thus facilitate market-based exchanges (Hoskisson et al., 2000). As a result, intermediaries in such regions are able to help EMEs enhance the effectiveness of OI by better linking firms with complementary interests and by providing them with information about potential exchange parties (McEvily and Zaheer, 1999). For example, well-developed innovation intermediaries such as venture capital firms in such regions can encourage external technological collaborations by reducing transaction costs and by facilitating information dissemination (Chesbrough, 2003). They can therefore contribute to the effectiveness of OI by decreasing innovation costs and time needed for opportunity search and the likelihood of finding appropriate paths to create value from appropriation of innovations.

By contrast, in regions with less developed intermediation markets, intermediaries have not been fully developed (Fan et al., 2011) or they are less efficient. These conditions constrain EMEs' access to reliable market information and complementary resources, increase business uncertainty and transaction cost for exchanges of factors and thus hampers the firm's ability capitalize on OI strategy (Makino et al., 
2002). Also, less developed markets of intermediation increases information asymmetry between exchanging parties that seek complementary knowledge, technology and resources. As a result, EMEs in those markets have to conduct costly search for factors, information and collaborators and tend to engage in unfair and opportunistic activities ( $\mathrm{Li}$ and Atuahene-Gima, 2001) which constrains their ability to take advantage of OI and improve innovation performance.

H3. The positive effects of open innovation on innovation performance will be higher for EMEs in regions with a higher level of development in intermediation markets than in regions with a lower level of development in intermediation markets.

\section{Data and methods}

\subsection{Sample}

Our data is drawn from a unique firm-level dataset entitled the 'Innovation-Oriented Firms Database' (IOFD) $)^{1}$, which is compiled annually by the Ministry of Science and Technology of China (MSTC). The MSTC collects such information as R\&D expenditures, $R \& D$ collaborations and $R \& D$ output in order to monitor the development of Chinese high-tech firms and provide potential inputs to policymaking. The database contains 443 innovative firms across China's regions for the period of 2008 and 2011. The selection of firms by MSTC is based on five dimensions of performance: the number of granted patents per thousand $R \& D$ personnel, $R \& D$ intensity, the ratio of new product sales to total sales, labor productivity, and innovations related to organizational change and management. Because this annual survey is mandatory for all qualified companies, it reduces the possibility of bias due to low response rates, which often happens in surveys. We checked for unusable or unreliable observations and excluded firms without complete information, as well as firms with missing values and outliers. We finally obtained a sample consisting of 438 firms between 2008 and 2011.

\footnotetext{
${ }^{1}$ The same dataset was used by Kafouros et al. (2015).
} 
Although the sample does not seem large relative to the population of Chinese high-tech firms, the surveyed firms are well represented in terms of ownership, industrial and geographic coverage (Kafouros et al., 2015). Nevertheless, to test the representativeness of the sample, we collected data from Annual Report of Industrial Enterprise Statistics in 2011, obtained from the State Statistical Bureau of China. The database includes manufacturing firms that account for about 90 percent of total output in most industries. To match our sample which contains innovation oriented high-tech firms only (many high-tech Chinese firms just involve OEM without substantial R\&D activities), we derived a further sub-sample (5,606 firms with above average R\&D intensity) out of the 11,212 high-tech firms in 2011 . We then used this sub-sample as the 'population' and tested the extent to which our sample represents the 'population' in terms of R\&D intensity and innovation performance by conducting $t$-tests. The results show no significant differences between our sample and the 'population' (the t ratios are 0.679 and 1.576 for R\&D intensity and innovation performance, respectively). Therefore, although our sample may be considered not very large, it can well represent the population of innovation oriented high-tech or $R \& D$ intensive firms in China.

\subsection{Measures}

\subsubsection{Dependent variable}

Our dependent variable is innovation performance which is measured by the ratio of new product sales to total sales (Kafouros et al., 2015). Because several firms have a value of zero for new product sales, we use ln (New product sales share +0.1$)$ in the model. New products are defined by the State Statistical Bureau of China as those goods that feature stronger functions or extended scope of usage as a result of the adoption of new structures, designs or manufacturing techniques (Wang et al., 2015). Because new product sales incorporate both market acceptance and non-patentable innovations, it has been widely used in previous studies (e.g., Berchicci, 2013; Laursen and Salter, 2006). By contrast, patent-based measures 
fail to capture innovations that are not amenable for patenting and innovations that the company does not want to patent.

\subsubsection{Independent variable}

$R \& D$ openness is measured as the ratio of external $\mathrm{R} \& \mathrm{D}$ expenditure to total $\mathrm{R} \& \mathrm{D}$ expenditure. The external R\&D expenditure covers all expenses related to collaborations with URIs, domestic and foreign firms, government agencies, foreign agencies, and the purchasing of foreign technology and facilities. These sources largely fall into the categories of 'market' and 'institutional' in the categorization of Lausen and Salter (2006). The high diversity of external knowledge sources that our sampled firms get access to increases their ability to adapt changes and therefore to innovate (Lausen and Salter, 2006; Luo et al., 2017). We measure region-specific IPR enforcement by the accumulated ratio of closed IPR cases to the total number of legal IPR cases entertained (Kafouros et al., 2015). Because there are significant discrepancies between the written laws and their enforcement at the local and subnational levels in China (Ang et al., 2014), our measure better capture IPR protection by focusing on the effectiveness of IPR enforcement rather than merely on the existence of IPR laws. Both region-specific factor market development and region-specific intermediation market development were constructed from the marketization index developed by NERI (Fan et al., 2007, 2011; Hong et al., 2015). The former covers financial markets, labour market and technology markets, while the latter includes market intermediaries (e.g., legal services, accounting services and industry associations) and innovation intermediaries. The NERI index provided a score for both variables for each of China's provinces, municipalities and autonomous regions and is widely used by scholars (e.g., Hong et al., 2015; Wang et al., 2015). A greater score indicates better market development.

\subsubsection{Control variables}

First, firm size is measured by the natural logarithm of total number of employees. Second, firm age is defined by the number of years since the firm was founded is included. Third, $R \& D$ intensity is measured 
by the ratio of $\mathrm{R} \& \mathrm{D}$ expenditure to the number of employees. Fourth, human resources are defined as the ratio of the number of technology people to the total number of employees. Fifth, return to assets is measured by the ratio of profit to total assets. Sixth, FDI penetration is defined as the ratio of amount of FDI to GDP in a region. Seventh, stock listed is defined as a dummy which equals to 1 for a company listed in stock markets. Finally, some additional dummies are included to account for idiosyncrasies associated with industry, region, and time variations. Table I summarizes the variables.

\section{(Insert Table I about here)}

\subsubsection{Descriptive analysis}

Table II shows that the average share of new product sales is 0.455 which is quite high but is not surprising because all firms in our sample are innovation oriented high-tech companies. Because these firms operate in high-tech industries characterized by short product life cycles, they must rely on the development of new products to remain competitive. The increasing new product sales share over the sample period was accompanied by rising R\&D openness and improving IPR enforcement and the development of factor and intermediation markets in subnational regions, highlighting the important role of OI and improving institutional conditions. The share of R\&D expenditure accounted for by URIs is less than $50 \%$, suggesting that the R\&D openness of the sampled firms is not largely driven by academic collaborations.

(Insert Table II about here)

\subsection{Statistical modeling}

We use the following regression specification to test our hypotheses:

$$
\mathrm{Y}_{\mathrm{it}}=\alpha+\mathrm{X}_{\mathrm{it}} \beta+\mathrm{M}_{\mathrm{it}} \gamma+\left(\mathrm{X}_{\mathrm{it}} \times \mathrm{M}_{\mathrm{it}}\right) \rho+\mathrm{Z}_{\mathrm{it}} \delta+\lambda_{\mathrm{j}}+\lambda_{\mathrm{k}}+\lambda_{\mathrm{t}}+\varepsilon_{\mathrm{it}}(1)
$$

Where, $Y_{i t}$ is the innovation performance, $X_{i t}$ is the R\&D openness, $M_{i t}$ denotes the three moderators - IPR enforcement, factor market development and intermediation market development, $\mathrm{X}_{\mathrm{it}} \times$ $\mathrm{M}_{\mathrm{it}}$ is the interaction terms between $\mathrm{R} \& \mathrm{D}$ openness and each of the three moderators, $\mathrm{Z}_{\mathrm{it}}$ is the control variables $, \lambda_{j}, \lambda_{k}$, and $\lambda_{t}$ are industry, region and time dummies, respectively, and $\varepsilon_{i t}$ is the error term. 
Table III reports correlations among the variables used in the model. The variance inflation factor (VIF) values ranged from 1.05 to 3.68 , well below the cutoff threshold of 10 . Nevertheless, we meancentered variables in the interaction terms to avoid problems of multicollinearity (Wang et al., 2015). In addition, we lagged all independent variables and interactions by one year to account for the fact that some of the predicted effects require time to materialize and also to offset any possible endogeneity concerns. Because the dependent variable $-R \& D$ performance has upper and lower bounds (i.e. ranges from 0 to 100), a panel-data Tobit model is applied (Wooldridge, 2002). Following Kafouros et al. (2015), random-effects models are used because the time period is short in our dataset and fixed-effects estimates cannot be made in a panel Tobit model.

(Insert Table III about here)

\section{Results}

Table IV reports the results. Model 1 includes control variables only. R\&D openness is added to Model 2 which serves as the baseline model. The coefficient of the R\&D openness variable is positive and statistically significant ${ }^{2}$. This result highlights the importance of opening up of innovation process for developing innovation and thus lends support for the theory of open innovation (Chesbrough, 2003). The interaction terms between R\&D openness and each of the three moderators are added in Models 3-5, respectively. The interaction term in Model 3 is positive and statistically significant. This suggests that the effect of OI on innovation performance is higher in regions with a higher level of IPR enforcement, supporting Hypothesis 1. Similarly, the interaction term in Model 4 is also positive and significant, corroborating Hypothesis 2. This result suggests that the effect of R\&D openness on innovation performance is pronounced in regions with a higher level of factor market development. The interaction term in Model 5 is marginally significant, lending weak support to Hypothesis 3. These results remain

\footnotetext{
${ }^{2}$ We have tried to include a squared term of the R\&D openness variable but the coefficient of this variable is insignificant. This suggests that our data do not support a curvilinear relationship between R\&D openness and innovation performance (Berchicci, 2013; Laursen and Salter, 2006).
} 
qualitatively unchanged in Model 6 which is a full model including all independent variables and interaction terms.

(Insert Table IV about here)

\section{Robustness test}

Although we control for possible estimation biases by incorporating several variables that account for firm characteristics, improvements in innovation performance can still lead to increase in $R \& D$ openness, causing a reverse-causality explanation of our results. We used an instrumental variable (IV) approach to solve this potential problem. To do so, it is necessary to choose a valid IV which should be highly correlated with the explanatory variable but has no (or very low) correlation with the error term. We use industry-level $R \& D$ openness - defined as the average ratio of the firm's external $R \& D$ expenditure to the total $R \& D$ expenditures in an industry, as the instrument for R\&D openness. We choose this variable because it may account for an important part of a firm's R\&D openness at the firm level, but it is less correlated with the individual firm's innovation performance. Moreover, $R \& D$ activities are not concentrated in a few large firms in high-tech industries which are emerging and dynamic sectors and are highly competitive. Our empirical tests show that the IV can explain $12.2 \%$ of the variance in $R \& D$ openness at the firm level (i.e., a strong predictor of the endogenous variable) but only $4.2 \%$ of the variance in innovation performance (i.e. it is a weak predictor of the dependent variable). We use this instrument to conduct the Dubin-Wu-Hausman tests. The results in Table 4 show that we cannot reject the null hypothesis in all models, indicating that the predictor variable (R\&D openness) is exogenous. Second, we use robust standard errors by employing the bootstrap method to overcome possible heterogeneity and autocorrelation problems in panel data. The results are very similar to those reported in Table 4 except for the coefficient of firm size which is becomes insignificant. Third, we used an approach that is employed in prior studies (e.g., Zhang et al., 2010) and regressed the R\&D openness 
on innovation performance. The analysis indicates that this relationship was statistically insignificant and thus the possibility of reverse causality can be ruled out in the current study ${ }^{3}$.

\section{Discussion and conclusion}

First, we find robust evidence that region-specific institutional idiosyncrasies, namely, levels of IPR enforcement and factor market development, positively moderate the performance effects of OI. These findings underscore the important role of institutional forces in unlocking the potential of OI strategy in emerging markets. As discussed in Section 2.1, previous studies have generated mixed predictions regarding the outcomes of OI. Our findings help to reconcile these conflicting predictions and advance this body of literature by demonstrating that variations in innovation performance can be explained not only by the degree of openness per se but also by institutional differences across subnational regions of a given country. Our study helps to explain why and how OI is more effective for some firms than for others.

Second, our study shows that the effect of OI is more pronounced in regions with stronger IPR enforcement and in regions with better-developed factor markets. These findings are intriguing because they indicate that while firms in a given country face the same macro-level institutions (North, 1990), those institutional forces at subnational levels are capable of explaining variations in the performance outcomes of OI. Our study therefore shifts the debate from whether OI matters for firm innovativeness to the question of how and under what institutional conditions it enhances innovation performance. Our attention on region-specific institutions complements and advances prior research on institutions and innovation by showing subnational regions to be a key unit of analysis for the determinants of the performance outcomes of OI in large emerging economies such as China. By showing the importance of capturing intra-national institutional diversity, our study also contributes to a broader understanding of 'how institutions matter' (Wright et al., 2005) and 'which institutions' are most relevant to a specific context or decision (Xu and Meyer, 2013).

\footnotetext{
${ }^{3}$ The results are available from the authors.
} 
However, we find that region-specific intermediation market development only has a weak positive effect on the relationship between R\&D openness and innovation performance. Our tentative explanation is that the marketization index which we used to measure intermediation market development may not comprehensively capture all types of intermediaries that support firms' external R\&D activities. Another possibility is that Chinese firms tend to collaborate increasingly with intermediaries in other regions. In such cases, the intermediation market development in their 'home regions' would matter less for implementing the OI strategy.

Our findings offer guidelines for EME managers by showing how they can benefit from OI by taking advantage of region-specific institutional environment (i.e. IPR environment and factor markets) in which their firms are embedded. EME managers should concern not only the extent to which they open the process of innovation but also treat regional institutions as an endogenous element of their firms' OI strategy. Instead of viewing the institutional environment as a source of contingencies to which organizations must adapt, EMEs should proactively and systematically integrate institutional advantages into their OI strategy. In terms of policy implications, our findings suggest that regional governments should strengthen IPR enforcement and encourage development of factor markets in their jurisdictions in order to help firms take advantage of OI strategy and enhance innovation. As these suggestions focus on external environments, they differ from prescriptions that emphasize merely how firms should open their internal $R \& D$ processes.

Nevertheless, this study has several limitations. First, it focuses on the interplay between open innovation strategy and regional institutional differences and, as a result, it places less emphasis on institutional variations across industries. Because each industry is coordinated by a unique configuration of institutional arrangements (Hollingsworth, 2000), future research should consider how industryspecific institutions influence the relationship between open innovation and firm innovativeness. Second, because we use data for Chinese high-tech firms, care should be taken to generalize our findings to other emerging economies and also to low-tech firms. Third, although both firms and the institutional environment in emerging markets evolve (Hong et al., 2015), the time length of our data does not allow 
the research to examine the co-evolution of firms and institutions and its consequences for open innovation. This is a promising research topic that warrants further investigation because it helps us understand how the value of open innovation can increase or decrease with dynamic shifts over time in institutional environment.

\section{References}

Ang, J. S., Cheng, Y., and Wu, C. (2014), "Does enforcement of intellectual property rights matter in China? Evidence from financing and investment Choices in the high-tech industry", The Review of Economics and Statistics, Vol.96 No.2, pp. 332-348.

Berchicci, L. (2013), “Towards an open R\&D system: Internal R\&D investment, external knowledge acquisition and innovative performance", Research Policy, Vol.42 No.1, pp. 117-127.

Caputo, M., Lamberti, E., Cammarano, A. and Michelino, F. (2016), "Exploring the impact of open innovation on firm performances", Management Decision, Vol.54 No.7, pp.1788-1812.

Chesbrough, H. (2003), “The era of open innovation”. Sloan Management Review, Summer: 35-41.

Choi, S. J., Jia, N. and Lu, J. (2015), "The structure of political institutions and effectiveness of corporate political lobbying”, Organization Science, Vol.26 No1, pp. 158-179.

Fan, G., Wang, X. L., Zhu, H. P., 2007. Marketization Index in China: The Regional Process Report of 2006. Economic Science Press, Beijing.

Fan, G., Wang, X. L. and Zhu, H. P. (2011), Marketization Index in China: The Regional Process Report of 2010. Economic Science Press, Beijing.

Hollingsworth, J. R., \& Boyer, R. (eds). (1997). Contemporary Capitalism: the Embeddedness of Institutions, New York: Cambridge University Press.

Hong, J., Wang, C. and Kafouros, M. (2015), “The role of the state in explaining the internationalization of emerging market enterprises", British Journal of Management, Vol.26 No.1, pp. 45-62. 
Hoskisson, R.E., Eden, L., Lau, C.M. and Wright, M. (2000), "Strategy in emerging economies", Academy of Management Journal, Vol.43 No.3, pp. 249-267.

Kafouros, M., Wang, C., Piperopoulos, P. and Zhang, M. (2015), “Academic collaborations and firm innovation performance in China: The role of region-specific institution", Research Policy, Vol.44 No.3, pp. 803-817.

Khanna, T. and Yafeh, Y. (2007), "Business groups in emerging markets: paragons or parasites", Journal of Economic Literature, XLV, pp. 331-372.

Laursen, K., \& Salter, A. (2006), "Open for innovation: The role of openness in explaining innovation performance among UK manufacturing firms", Strategic Management Journal, Vol.27 No.2, pp. $131-150$.

Laursen, K., \& Salter, A. (2014), "The paradox of openness: Appropriability, external search and collaboration", Research Policy, Vol. 43 No.5, pp. 867-878.

Lhuillery, S. and Pfister, E. (2009), "R\&D cooperation and failures in innovation projects: empirical evidence from French CIS data", Research Policy, Vol.38, No.1, pp. 45-57.

Li, X. (2012), "Behind the recent surge of Chinese patenting: An institutional view", Research Policy, Vol.41 No.1, pp. 236-249.

Li, H. and K. Atuahene-Gima (2001), "Product innovation strategy and the performance of new technology ventures in China”, Academy of Management Journal, Vol.44 No.6, pp. 1123-34.

Lin, Z., Peng, M. W., Yang, H. and Sun, S. L. (2009), "How do networks and learning drive M\&As? An institutional comparison between China and the United States", Strategic Management Journal, Vol. 30 No. 10, pp. 1113-1132.

Laursen, K. and Salter, A. (2006), “Open for innovation: The role of openness in explaining innovation performance among UK manufacturing firms”, Strategic Management Journal, Vol.27 No.2, pp. $131-150$.

Laursen, K., and Salter, A. (2014), "The paradox of openness: Appropriability, external search and collaboration", Research Policy, Vol. 43 No.5, pp. 867-878. 
Levine, R., (1997), "Financial development and economic growth: views and agenda", Journal of Economic Literature, Vol. 35 No.2, pp. 688-726.

Lin, Z., Peng, M. W., Yang, H. and Sun, S. L. (2009), "How do networks and learning drive M\&As? An institutional comparison of China and the United States", Strategic Management Journal, Vol.30 No. 10, pp. 1113-32.

Luo, B.N., Lui, S.S. and Kim, Y. (2017), “The relationship between knowledge search breadth and firm innovation: A knowledge transfer perspective”, Management Decision, Vol.55 No.1, pp. 214.

Jacobides, M. G., Knudsen, T. and Augier, M. (2006), "Benefiting from innovation: Value creation, value appropriation and the role of industry architectures", Research Policy, Vol.35 No.8, pp. 1200-1221.

Makino, S., Lau, C. M. and Yeh, R. S. (2002), “Asset-exploitation versus asset-seeking: Implications for location choice of foreign direct investment from newly industrialized economies", Journal of International Business Studies, Vol.33 No.3, pp. 403-421.

McEvily, B. and Zaheer, A. (1999), "Bridging ties: A source of firm heterogeneity in competitive capabilities", Strategic Management Journal, Vol.20 No.12, pp. 1133-56.

Memili, E., Fang, H. C. and Welsh, D. H. B. (2015), "Value creation and value appropriation in innovation process in publicly-traded family firms”, Management Decision, Vol.53 No.9 pp. 19211952.

Nelson, R. R. (1988), "Institutions supporting technical change in the United States", in Dosi, G., Freeman, C., Nelson, R.R., Silverberg, G., \& Soete, L.,(eds.), Technology and economic theory, London, Pinter Publishers.

Noh, Y. (2015), "Financial effects of open innovation in the manufacturing industry", Management Decision, Vol. 53 No.7, pp. 1527-1544.

North, D. C. (1990), Institutions Institutional Change and Economic Performance. Cambridge University Press, Cambridge, MA. 
Peng, Mike W. (2003), "Institutional transitions and strategic choices", Academy of Management Review, Vol.28 No.2, pp. 275-296.

Scott, W. R. (1995). Institutions and organizations. Thousand Oaks, CA: Sage.

Wang, C., Yi, J., Kafouros, M. and Yan, Y. (2015), "Under what institutional conditions do business groups enhance innovation performance?", Journal of Business Research, Vol.68 No.3, pp. 694-702. Wooldridge, J. (2002), Econometric Analysis of Cross Section and Panel Data. MIT press, Cambridge.

Wright, M., Filatotchev, I., Hoskisson, R. and Peng, M. W. (2005), "Strategy research in emerging economies: challenging the conventional wisdom”, Journal of Management Studies, Vol.42 No.1, pp. $1-34$.

Wu, S. D. (2004), “A bargaining theoretic framework: Supply chain intermediation”. In David SimchiLevi, S. D. Wu, \& Z. Shen Max (Eds.), Handbook of quantitative supply chain analysis: Modeling in the e-business era. Boston: Kluwer Academic Publishers.

Wu, J. and Olk, P. (2014), “Technological advantage, alliances with customers, local knowledge and competitor identification”, Journal of Business Research, Vol.67 No.10, pp. 2106-2114.

Xu, D. and Meyer, K. E. (2013), “Linking theory and context: 'Strategy research in emerging economies' after Wright et al. (2005)' ”, Journal of Management Studies. Vol.50 No.7, pp. 1322-46.

Zhang, Y., Li, H., Li, Y. and Zhou, L. A. (2010), "FDI spillovers in an emerging market: The role of foreign firms' country origin diversity and domestic firms' absorptive capacity", Strategic Management Journal, Vol.31 No.9, pp. 969-989.

Zhang, D., Li, S. and Zheng, D. (2017), "Knowledge search and open innovation performance in an emerging market: Moderating effects of government-enterprise relationship and market focus", Management Decision, Vol.55 No.4, pp. 634-647. 
Table I

Definitions and descriptions of variables

\begin{tabular}{|c|c|c|c|}
\hline Variables & Definition & Mean & S.D. \\
\hline Innovation performance & $\ln ($ New product share $* 100+1)$ & 3.470 & 1.121 \\
\hline R\&D openness & $\begin{array}{l}\text { Ratio of external } R \& D \text { expenditure to total } R \& D \\
\text { expenditure }\end{array}$ & 0.101 & 0.139 \\
\hline IPR enforcement & $\begin{array}{l}\text { Ratio of accumulated closed IPR cases to the total } \\
\text { number of legal IPR cases entertained }\end{array}$ & 0.895 & 0.070 \\
\hline Factor market development & $\begin{array}{l}\text { Province-specific factor market development index } \\
\text { by Fan et al. }(2008-2011)\end{array}$ & 6.275 & 1.538 \\
\hline Interm. market development & $\begin{array}{l}\text { Province-specific intermediation market development } \\
\text { index by Fan et al. (2008-2011) }\end{array}$ & 5.122 & 3.100 \\
\hline Firm age & The number of years since the firm was founded & 13.30 & 7.059 \\
\hline Firm size & $\ln$ (Number of employees) & 8.060 & 1.854 \\
\hline Share of gov. funding & $\begin{array}{l}\text { Ratio of } R \& D \text { expenditure from government sources } \\
\text { over total } R \& D \text { expenditure }\end{array}$ & 0.123 & 0.228 \\
\hline Human resources & $\begin{array}{l}\text { Ratio of the number of technology people to the } \\
\text { number of employees }\end{array}$ & 0.286 & 0.193 \\
\hline Return to assets & Ratio of profits to total assets & 0.078 & 0.090 \\
\hline R\&D intensity & $\begin{array}{l}\text { Ratio of } R \& D \text { expenditure to the total number of } \\
\text { employees }\end{array}$ & 4.356 & 7.535 \\
\hline FDI penetration & Ratio of amount of FDI to GDP in a region & 0.029 & 0.018 \\
\hline Stock listed & $\begin{array}{l}\text { Dummy variable, equals to } 1 \text { if a firm is listed in stock } \\
\text { market }\end{array}$ & 0.518 & 0.500 \\
\hline
\end{tabular}


Table II.

Descriptive statistics

\begin{tabular}{|l|l|l|l|l|l|l|}
\hline & $\begin{array}{l}\text { R\&D } \\
\text { openness }\end{array}$ & $\begin{array}{l}\text { Expenditure for } \\
\text { collaborations with } \\
\text { URIs/Total external } \\
\text { R\&D expenditure }\end{array}$ & $\begin{array}{l}\text { New product } \\
\text { sales share }\end{array}$ & $\begin{array}{l}\text { Region-specific } \\
\text { IPR enforcement }\end{array}$ & $\begin{array}{l}\text { Region-specific } \\
\text { factor market } \\
\text { development }\end{array}$ & $\begin{array}{l}\text { Region-specific } \\
\text { interm. market } \\
\text { development }\end{array}$ \\
\hline 2008 & 0.068 & 0.368 & 0.411 & 0.889 & 6.152 & 4.588 \\
\hline 2009 & 0.080 & 0.356 & 0.432 & 0.889 & 6.244 & 5.058 \\
\hline 2010 & 0.134 & 0.401 & 0.480 & 0.901 & 6.263 & 5.267 \\
\hline 2011 & 0.120 & 0.420 & 0.497 & 0.902 & 6.441 & 5.574 \\
\hline Average & 0.101 & 0.386 & 0.455 & 0.895 & 6.275 & 5.122 \\
\hline
\end{tabular}


Table III.

Correlation matrix

\begin{tabular}{|c|c|c|c|c|c|c|c|c|c|c|c|c|}
\hline Variable & 1 & 2 & 3 & 4 & 5 & 6 & 7 & 8 & 9 & 10 & 11 & 12 \\
\hline 1. Innovation Perf. & 1.000 & & & & & & & & & & & \\
\hline 2. $R \& D$ openness & -0.071 & 1.000 & & & & & & & & & & \\
\hline 3. IPR enforcement & -0.158 & 0.026 & 1.000 & & & & & & & & & \\
\hline 4.Factor market & 0.062 & -0.071 & 0.058 & 1.000 & & & & & & & & \\
\hline 5. Interm. market & -0.023 & -0.061 & 0.121 & 0.480 & 1.000 & & & & & & & \\
\hline 6.Firm age & -0.070 & -0.069 & 0.007 & 0.120 & 0.113 & 1.000 & & & & & & \\
\hline 7. Firm size & -0.194 & 0.051 & 0.100 & 0.212 & 0.224 & 0.315 & 1.000 & & & & & \\
\hline 8. Share of gov. funding & -0.017 & 0.015 & 0.039 & -0.047 & -0.021 & -0.125 & -0.278 & 1.000 & & & & \\
\hline 9. Human resources & 0.142 & -0.125 & -0.022 & 0.025 & 0.004 & -0.144 & -0.515 & 0.286 & 1.000 & & & \\
\hline 10. Return to assets & 0.045 & 0.068 & -0.039 & 0.026 & -0.018 & -0.086 & -0.189 & -0.031 & 0.145 & 1.000 & & \\
\hline 11. $R \& D$ intensity & 0.037 & 0.043 & 0.074 & 0.103 & 0.105 & -0.029 & -0.144 & -0.020 & 0.225 & -0.004 & 1.000 & \\
\hline 12. FDI penetration & 0.016 & -0.045 & 0.090 & 0.511 & 0.411 & 0.020 & -0.018 & 0.029 & 0.138 & 0.033 & 0.092 & 1.000 \\
\hline 13. Stock listed & -0.062 & -0.028 & 0.006 & 0.037 & 0.082 & 0.203 & 0.478 & -0.148 & -0.263 & -0.115 & -0.048 & -0.046 \\
\hline
\end{tabular}

Table IV.

Regression results

$\begin{array}{llllll}\text { Model } 1 & \text { Model } 2 & \text { Model } 3 & \text { Model 4 } & \text { Model 5 } & \text { Model } 6\end{array}$

Independent variable 
R\&D openness

\section{Moderators}

IPR enforcement

Factor market

Interm. market

\section{Interactions}

R\&D open*IPR

enforcement

R\&D open*Factor market

R\&D open* Interm. market

\section{Control variables}

\begin{tabular}{|c|c|c|c|c|c|c|}
\hline Firm age & -0.009 & -0.008 & -0.008 & -0.009 & -0.008 & -0.008 \\
\hline Firm size & $-0.054^{*}$ & $-0.055^{*}$ & -0.047 & $-0.065^{* *}$ & $-0.054^{*}$ & $-0.059^{* * *}$ \\
\hline Share of gov. funding & 0.092 & 0.084 & 0.074 & 0.084 & 0.085 & 0.078 \\
\hline Human resources & $0.525^{* *}$ & $0.568^{* * * *}$ & $0.601^{* * *}$ & $0.548^{* * *}$ & $0.571^{* * *}$ & $0.585^{* * *}$ \\
\hline Return to assets & 0.438 & 0.422 & 0.427 & 0.400 & 0.412 & 0.308 \\
\hline R\&D intensity & -0.001 & -0.001 & -0.002 & -0.002 & -0.002 & -0.002 \\
\hline FDI penetration & 1.393 & 1.419 & 1.447 & -0.454 & 1.701 & -2.362 \\
\hline Stock listed & 0.075 & 0.081 & 0.068 & 0.088 & 0.079 & 0.103 \\
\hline Year dummies & Yes & Yes & Yes & Yes & Yes & Yes \\
\hline Industry dummies & Yes & Yes & Yes & Yes & Yes & Yes \\
\hline Region dummies & Yes & Yes & Yes & Yes & Yes & Yes \\
\hline Observations & 1,752 & 1,752 & 1,752 & 1,752 & 1,752 & 1752 \\
\hline Wald Chi2 test & $141.4^{* * * *}$ & $143.8^{* * *}$ & $157.2^{* * *}$ & $149.8^{* * *}$ & $144.6^{* * *}$ & $185.4^{* * *}$ \\
\hline Log likelihood function & -2348 & -2346 & -2341 & -2345 & -2346 & -2331 \\
\hline Left or right censored & 59 & 59 & 59 & 59 & 59 & 59 \\
\hline Rho & 0.501 & 0.504 & 0.496 & 0.498 & 0.505 & 0.484 \\
\hline D-W-Hausman & 10.47 & 10.63 & 10.96 & 10.20 & 10.57 & 9.09 \\
\hline
\end{tabular}

$-1.454^{* *}$

$0.057^{* *}$

$-1.180^{* * *}$

$0.239^{* * * *}$

$\begin{array}{ll}-0.007 & -0.090\end{array}$

$4.047^{* * *}$

$3.342^{* * *}$

$0.022^{* *}$

$0.027^{* *}$

$0.048^{*}$

$0.164^{*}$

Notes: $* \mathrm{p}<0.1, * \mathrm{p}<0.05, * * \mathrm{p}<0.01, * * * \mathrm{p}<0.001$ 